DOI: 10.34015/2523-4552.2020.1.05

УдК 343.8

Колб О. Г.,

доктор юридичних наук, професор,

професор кафедри кримінального права

та процесу Національного університету

«Львівська політехніка»

ORCID: 0000-0003-1792-4739

Дучимінська Л. М.,

начальник управління контрольно-

перевірочної роботи головного управління

Пенсійного фонду України у Волинській

області

\title{
СУЧАСНА ПОЛІТИКА У СФЕРІ ВИКОНАННЯ ПОКАРАНЬ УКРАЇНИ: ЗМІСТ ТА ОСОБЛИВОСТІ
}

У статті визначено сутність і зміст сучасної державної політики у сфері виконання покарань і пробації України, а також встановлені її особливості та розроблені науково обгрунтовані заходи, спрямовані на удосконалення форм iї реалізації на законодавчому та практичному рівнях, з урахуванням діючих на сьогодні державних стратегій та концепцій реформування органів та установ виконання покарань.

Ключові слова: політика; сфера виконання покарань; стратегія; концепція; орган виконання покарань; установа виконання покарань; реформування; пробація.

В статье определена сущность и содержание современной государственной политики в сфере исполнения наказаний и пробации Украины, а также установлены ее особенности и разработаны научно обоснованные мероприятия, направленные на совершенствование форм ее реализации на законодательном и практическом уровнях, с учетом действующих на сегодня государственных стратегий и концепций реформирования органов и учреждений исполнения наказаний.

Ключевые слова: политика; сфера исполнения наказаний; стратегия; концепция; орган исполнения наказаний; учреждение исполнения наказаний; реформирование; пробация; реализация.

Постановка проблеми. У наукових джерелах під політикою розуміють загальний напрямок, характер діяльності держави, певного класу або політичної партії [1, с. 524]. Виходячи 3 цього, прийнято виділяти зов- нішню та внутрішню політику держави. У свою чергу, учені, у залежності від сфери суспільних відносин, виокремлюють правову, соціальну, економічну, культурну та інші підвиди внутрішньої політики партії [2, с. 147]. 
Саме одним із видів правової політики є державна політика у сфері виконання покарань України, хоча на доктринальному рівні у більшій мірі мова ведеться про кримінальновиконавчу політику [2], а також про пенітенціарну політику [3].

Виходячи з теоретичних постулатів про елементи реалізації державної політики у сфері виконання покарань (нормативно-правовому; організаційно-інституційному; гарантійному; ресурсно-забезпечувальному; функціональному (інструментальному) [2, с. 199], а також враховуючи зміст предмета даного дослідження, досить важливо 3 огляду цього визначити через аналіз законодавчих актів України сутність зазначеного підвиду внутрішньої політики України.

У першу чергу, мова ведеться про ч. 2 ст. 1 КВК України, у якій зазначені такі завдання кримінальновиконавчого законодавства: 1) визначення принципів виконання кримінальних покарань, правового статусу засуджених, гарантій захисту їхніх прав, законних інтересів та обов'язків; 2) визначення порядку застосування до них заходів впливу 3 метою виправлення і профілактики асоціальної поведінки; 3) визначення системи органів і установ виконання покарань, їх функцій та порядку діяльності; 4) визначення порядку нагляду і контролю за виконанням кримінальних покарань, участі громадськості в цьому процесі; 5) регламентація порядку і умов виконання та відбування кримінальних покарань; 6) регламентація порядку звільнення від відбування покарання, допомоги особам, звільненим від покарання, контролю і нагляду за ними.
Отже, лише поверхове співставлення законодавчо визначених завдань державної політики у сфері виконання покарань України із завданнями пенітенціарної політики, що визначені на науковому рівні, дає підстави стверджувати, що вони не $\epsilon$ тотожними (схожими, подібними).

Постановка завдання. Саме це обумовило вибір теми цієї статті, iї актуальність теоретичне та практичне значення, а також визначило i головне завдання - розробити науково обгрунтовані заходи, спрямовані на удосконалення форм її реалізації на законодавчому та практичному рівнях, з урахуванням діючих на сьогодні державних стратегій та концепцій реформування органів та установ виконання покарань.

Аналіз останніх досліджень і публікацій. Вивчення наукової літератури показало, що досить активно та предметно займаються розробкою питань 3 означеної проблематики дослідження такі науковці, як: К. А. Автухов, О. М. Богатирьов, В. А. Бадира, Б. М. Головкін, О. М. Джужа, Т. А. Денисова, В. Я. Конопельський, І. М. Копотун, В. О. Меркулова, $\begin{array}{ll}\text { А.Х. Степанюк, } & \text { В. М. Трубников, }\end{array}$ С. Я. Фаренюк, І. С. Яковець.

Поряд з цим, у контексті вибраної у цій науковій статті тематики, дослідження учених носять одиничний та безсистемний характер, що й виступило додатковою підставою для постановки даного питання саме у такій площині.

Виклад основного матеріалу. Як показали результати даного дослідження, більшість доктринальних та нормативно-правових розробок, що стосуються змісту та реалізації сучасної державної політики у сфері виконання покарань та пробації 
України, носять однотипний характер та відображають помилки методологічного характеру 3 означеної проблематики. Зокрема, розробники сучасної Концепції реформування (розвитку) пенітенціарної системи України [4] ніякої різниці не бачать між змістом кримінально-виконавчої та пенітенціарної системи, хоча їх відмінності $є$ очевидними та доведені на науковому рівні. Більш того, їі автори збираються, як це витікає із назви та змісту даної Концепції, реформувати та розвивати те, чого на законодавчому, організаційноуправлінському, практичному та інших рівнях реалізації державної політики у сфері виконання покарань, не створено.

Такий висновок у тому числі витікає із переліку тих основних завдань реформи, які закріплені у цій Концепції, а саме - це: 1) залучення нових кадрів у систему на всіх рівнях - насамперед за рахунок підвищення рівня заробітної плати; 2) розроблення законодавства у сфері функціонування СІЗО та УВП відповідно до законодавства Європейського Союзу; 3) підвищення операційної ефективності 100 державних підприємств в пенітенціарній системі за рахунок створення виробничих об'єднань за галузевим принципом, проведення закупівель через електронну систему «ProZorro»; 4) будівництво нових слідчих ізоляторів та установ виконання покарань у великих містах України в рамках державно-приватного партнерства.

Отже, якщо виходити з етимологічного значення слова «система» (порядок, зумовлений правильним, планомірним розташуванням і взаємним зв'язком частин чого-небудь $[1$, c. 609]), то про яку пенітенціарну систему можна говорити, якщо навіть серед завдань зазначеної Концепції відсутні такі із них, як: а) розробка пенітенціарного (а не, знову ж таки, узагальнення (своєрідний «ретуш» (фр. retouch - виправлення, підмалювання малюнка [5, с. 501])) законодавства України; б) будівництво сучасних пенітенціарних установ, а не будівництво установ виконання покарань, які $€$ системною ознакою кримінальновиконавчої, а не пенітенціарної системи; в) створення інших елементів пенітенціарної системи, про які у свій час писав у своїх працях Г. О. Радов, а саме: 1) сучасна пенітенціарна політика повинна будуватись на принципах суверенітету, наукової обгрунтованості і незалежності від ідеологічних установок і рішень політичних партій і течій, пріоритету загальновизнаних людських цінностей, життя і здоров'я людини, прилату прав людини над державними і суспільними інтересами; гуманізму і милосердя, справедливості і моральності, максимального використання інститутів соціалізації, які $\epsilon$ в розпорядженні держави і суспільства; ін. [6, с. 14-15]; 2) головними пріоритетам пенітенціарної політики мають бути об'єднання навколо пенітенціарних установ усіх суб’єктів місцевого соціального життя з метою надання цим установам додаткової допомоги i підтримки людськими ресурсами, коштами і матеріалами; забезпечення всебічного контролю за дотриманням пенітенціарним персоналом вимог чинного законодавства, створення в пенітенціарних установах умов, стверджуючих загальнолюдські цінності, культуру людини, ідеали добра, справедливості і гуманізму, які б давали засудженим 
уроки моральності, милосердя, людяності тощо; інші пріоритети [6, с. 13-14].

Якщо розглянути зміст Концепції реформування (розвитку) пенітенціарної системи України 3 огляду видозміни змісту правових засад i практики застосування до засуджених у місцях позбавлення волі заходів вгамування, то і в даному випадку говорити про пенітенціарну політику не приходиться, позаяк з цього приводу нічого не сказано. Зокрема, ні серед мети Концепції (р. II), ні серед проблем, які потребують розв'язання (р. III), ні серед шляхів і способів їх вирішення (p. IV) не закріплено таке завдання, як зміна психології персоналу органів та установ виконання покарань щодо відношення цих осіб до засуджених (на партнерські, людські, відносини взаємної поваги і допомоги; т. ін.). Поряд з цим, у Концепції є чітко виражені рудименти (лат. rudimentum зачаток, початковий рівень; слід явища, яке зникло) [5, с. 510] виправно-трудової та кримінальновико-навчої політики, про що свідчать такі їі положення: 1) метою Концепції є гуманізація кримінально-виконавчого механізму, а не створення пенітенціарних засад державної політики у сфері виконання покарань України (р. II); 2) реформування пенітенціарної системи в Концепції передбачається шляхом удосконалення законодавства, що регламентує діяльність ДКВС України (р. IV), а не створення пенітенціарних установ та пенітенціарного законодавства; 3) для реалізації зазначених положень розділів II та IV Концепції запропоновано: а) забезпечити територіальні (міжрегіональні) воєнізовані формування ДКВС
України сучасним озброєнням, спеціальними засобами, індивідуальними засобами захисту та засобами активної оборони (р. IV), існування яких у пенітенціарній системі, зокрема у країнах $€ C, \epsilon$ недопустимим (п. п. 64.1-67.3 ЄПП); б) модернізувати наявні технічні засоби охорони, у тому числі системи відеоспостереження в УВП і CI30 (p. IV); в) оптимізувати охорону УВП і CI30 (p. IV); г) поліпшити заходи безпеки в УВП і СІ30; ґ) максимально залучати громадські організації до роботи із засудженими (р. IV), а не посилити громадський контроль за діяльністю персоналу органів та УВП.

Такими ж нелогічними та безсистемними, 3 огляду вирішення проблем кримінально-виконавчої діяльності $€$ й заходи, що закріплені в інших нормативно-правових актах України. Зокрема, в Законі України «Про національну безпеку» даний аспект функціонування сфери виконання покарань лише у загальних рисах відображений у певних його нормах. Так, у ч. 2 ст. 12 «Склад сектору безпеки і оборони» цього Закону зазначено, що інші державні органи здійснюють свої функції із забезпечення національної безпеки $\mathrm{y}$ взаємодії з органами, які входять до складу сектору безпеки i оборони. При цьому, до даного складу ні Міністерство юстиції України як центральний орган виконавчої влади, що реалізує державну політику у сфері виконання покарань та пробації, ні Адміністрація ДКВС України, як структурний підрозділ Мінюсту, який безпосередньо відповідає за реалізацію даної політики, до складу сектору безпеки і оборони України не входять [7]. Більш того, якщо у розділі IV «Сектор безпеки і оборо- 
ни» Закону України «Про національну безпеку» кожному члену складу сектору безпеки i оборони чітко визначені повноваження 3 цих питань (ст. ст. 15-24), то про повноваження інших державних органів 3 означених питань мова у цьому нормативно-правовому акті взагалі не ведеться. У той самий час, виходячи 3 положень ст. 1 даного Закону, в якій дано визначення термінів (громадська безпека і порядок; державна безпека; національна безпека України; т. ін.), слід визнати, що наявність органів та установ виконання покарань у секторі безпеки і оборони є очевидною. Додатковим аргументом $з$ цього приводу виступають положення ч. 2 ст. 26 Закону України «Про національні безпеку», в якій у змісті стратегії національної безпеки України закріплено вимога про те, що вона визначає пріоритети національних інтересів України та забезпечення національної безпеки, цілі, основні напрями державної політики у сфері національної безпеки. Крім цього, про необхідність включення до складу сектору безпеки і оборони Міністерства юстиції України або ДКВС (у випадку надання їй автономності чи самостійності) свідчить як кількісно-якісний склад засуджених, які тримаються у місцях позбавлення волі, 70 \% із яких притягнуті до кримінальної відповідальності за вчинення тяжких та особливо тяжких злочинів (ч. ч. 4, 5 ст. 12 КК), так і щорічне вчинення цими особами у ході відбування покарання злочинів проти правосуддя, $40 \% 3$ яких пов'язані із злісною непокорою адміністрації УВП (ст. 381 КК), діями, що дезорганізують роботу УВП (ст. 392), та втечами з колоній і виправних центрів.
I, на кінець, у структурі всіх застосувань до засуджених, позбавлених волі, фізичної сили, спеціальних засобів і зброї більше $70 \%$ приходиться на подолання фізичного опору, буйства та інших проявів непокори цих осіб персоналу органів та УВП. Виходячи з цього, можна було б, ч. 2 ст. 12 Закону України «Про національну безпеку» доповнити таким членом сектору безпеки і оборони, як центральний орган виконавчої влади, що реалізує державну політику у сфері виконання покарань. Крім цього, варто цей Закон доповнити ст. 231 «Центральний орган виконавчої влади, що реалізує державну політику у сфері виконання покарань» такого змісту: «Центральний орган виконавчої влади, що реалізує державну політику у сфері виконання покарань, разом з іншими членами сектору безпеки і оборони визначає пріоритетні напрями забезпечення громадського порядку і безпеки в установах виконання покарань та слідчих ізоляторах у цій сфері суспільних відносин, аналізує стан та тенденції розвитку кримінальновиконавчої системи та організовує виконання стратегії національної безпеки України у межах визначених у законі повноважень».

Як показали результати даного дослідження, дуже багато правових прогалин, що стосуються процесу виконання і відбування покарань та, зокрема, питань застосування заходів вгамівного характеру в місцях позбавлення волі, $\epsilon$ й у Національній стратегії у сфері прав людини, яка затверджена Указом Президента України від 25 серпня 2015 року № 501/2015. Так, закріпивши у Загальній частині даної стратегії необхідність вдосконалення діяльності 
держави щодо утвердження та забезпечення прав, свобод людини i створення дійового механізму захисту в Україні з цих питань, а також завдання щодо вирішення у зв'язку з цим системних проблем у зазначеній сфері, їі автори серед стратегічних напрямів не визначили такий із них, як «забезпечення прав i законних інтересів засуджених та осіб, які тримаються в місцях позбавлення волі, а також персоналу органів та установ виконання покарань», що $\epsilon$ вкрай необхідним заходом з огляду існуючих проблем 3 означених питань у сфері виконання покарань. У той самий час, про її вирішення лише частково ведеться мова у таких підрозділах та розділах Національної стратегї:

1. У підрозділі «Забезпечення права на життя» розділу 4 «Стратегічні напрями» зазначено, що життя людини $\epsilon$ найвищою соціальною цінністю. У сучасних умовах обов'язок держави захистити життя людини набуває особливого змісту, враховуючи існуючі проблеми, зокрема, непропорційне використання сили та спеціальних засобів працівниками правоохоронних органів. Отже, у Стратегії мова про зміну психології правоохоронців та в цілому практики застосування заходів вгамування, а також про можливість вирішення будь-яких конфліктів у суспільстві (індивідуальних чи колективних) заходами запобіжного характеру, включаючи вербальні методи, не ведеться. Звичайно, що при такій державній політиці навряд чи можна змінити існуючий стан речей й у сфері виконання покарань України. I, це при тому, що у р. 1 «Загальна частина» цієї Стратегї зазначено, що події Революції гідності (листопад
2013 р. - лютий 2014 р.) засвідчили недвозначне прагнення українського народу до побудови правової та демократичної держави, в якій гарантуються та забезпечуються права i свободи людини. При цьому стратегічною метою заходів, що закріплені у п. 1 р. 4 Стратегії $€$ забезпечення належних гарантій захисту права на життя та наявність правових засобів захисту механізмів ефективного розслідування порушень права на життя, а очікуваними результатами $\epsilon$ відповідність міжнародним стандартам захисту права на життя, умови тримання та поводження з особами у місцях, в яких вони примусово перебувають за судовим рішенням відповідно до закону.

Аналогічна мета визначена й у підрозділі 2 «Протидія катуванню, жорстокому, нелюдському або такому, що принижує гідність, поводженню чи покаранню» розділ 1 даної Стратегії, а також у п. 3 «Забезпечення права на свободу та особисту недоторканість» цього розділу.

2. У певній мірі стосуються означеної проблематики й інші підрозділи Національної стратегії (попередження та протидія дискримінації; забезпечення рівних прав та можливостей жінок і чоловіків; забезпечення права на охорону здоров'я; забезпечення права на освіту; забезпечення прав дитини; звільнення заручників та відновлення їхніх прав; ін.), які можна було б розмістити у спеціальному розділі, що присвячений забезпеченню прав i законних інтересів осіб, які тримаються у місцях позбавлення волі, включаючи й питання, які мають пряме відношення до застосування заходів вгамування до засуджених, позбавлених волі. 
3. Важливими у цьому сенсі $€$ положення, що визначені у підрозділі «Реалізація, моніторинг та контроль за імплементацією Стратегії», відповідно до яких для здійснення моніторингу реалізації Стратегії Президентом України, Кабінетом Міністрів України можуть утворюватися відповідні допоміжні органи, до складу яких можуть залучатися в установленому порядку представники державних органів, інститутів громадянського суспільства, Уповноваженого Верховної Ради з прав людини, міжнародних організацій, народні депутати, науковці та інші фахівці.

Як показали результати даного дослідження, у прямій постановці відсутнє питання про дотримання прав людини у місцях позбавлення волі, у тому числі при застосуванні заходів вгамування до засуджених, позбавлених волі й в Стратегії сталого розвитку «Україна - 2020», яка затверджена Указом Президента України від 12.01.2015 № 5/2015. Поряд 3 цим, загальні концептуальні положення даної Стратегії можна було б використати при удосконаленні правових засад і практики застосування фізичної сили, спеціальних засобів і зброї до засуджених, позбавлених волі, а саме - при реалізації: а) мети Стратегії, відповідно до якої в Україні мають бути впровадженні Європейські стандарти життя, а також ії̈ реалізації через можливості вектора безпеки (розділ 1); б) заходи, що стосуються реформи правоохоронної системи (п. 4 р. 1), метою яких $\epsilon$ коригування завдань та функцій правоохоронних органів, впровадження нових засад проходження служби, нових критеріїв оцінки роботи правоохоронців для під- вищення рівня захисту прав і свобод, а також інтересів суспільства і держави від протиправних посягань; в) заходів спрямованих на оновлення кадрового складу державних службовців у правоохоронних органах на 70 \% (п. 14 р. 4 Стратегії); г) головної передумови реалізації Стратегії, відповідно до якої визнано суспільний договір між владою та громадським суспільством, де кожна сторона має свою зону відповідальності. Зокрема, відповідальність громадського суспільства у цій Стратегії тлумачиться як діяльність щодо контролю влади, життя відповідно до принципів гідності та неухильного додержання Конституції України та Законів України (р. 5 Стратегії «Засоби реалізації Стратегії (суспільний договір)»; г) заходів, пов'язаних із нормативноправовим забезпеченням даної Стратегії, згідно якої має стати розробка та прийняття відповідних нормативно-правових актів (такою, зокрема, для сфери виконання покарань стала Концепція реформування (розвитку) пенітенціарної системи України, яка була схвалена розпорядженням Кабінету Міністрів України від 13.09.2017 № 654-p).

Таким чином, слід визнати, що і в Стратегії сталого розвитку «Україна - 2020» також не закріплені ті концептуальні положення, що мають пряме відношення до забезпечення безпечних умов життєдіяльності в місцях позбавлення волі.

Аналогічні правові прогалини, як встановлено в ході даного дослідження, мають місце й в Стратегії реформування судоустрою, судочинства та суміжних правових інститутів на 2015-2020 роки, схваленої Указом Президента України 20.05.2015 № 276/2015. I це при тому, що в її 
розділі 1 «Загальні положення» 3 цього приводу зазначено, що дана Стратегія визначила мету вектора руху, дорожню карту, першочергові пріоритети політико-правових умов становлення та розвитку України, а метою Стратегії $\epsilon$ практична реалізація принципу верховенства права, що важливо з огляду вирішення тих проблем, які стосуються сфери виконання покарань (розділ 2). У свою чергу, одним із завдань Стратегії $€$ окреслення поля проблем і визначення їх причин, які необхідно усунути шляхом реформування судоустрою, судочинства та суміжних правових інститутів, що виступило додатковим аргументом при виборі теми даного дослідження та затвердженні його відповідних завдань. Немаловажним у цьому контексті завданням, яке зазначено у даній Стратегії, $\epsilon$ те, що пов'язане з підвищенням ступеня довіри населення до органів судової влади та суміжних правових інститутів. Поряд з цим, у п. 5.11 розділу 5 цієї Стратегії означеній у цій роботі проблематиці присвячено лише два із семи затверджених заходів, а саме: 1) розробка та практичне застосування сучасних підходів до управління пенітенціарними установами (п. 1); 2) вдосконалення етичних та дисциплінарних правил і механізмів внутрішнього контролю в пенітенціарних установах (п. 2), мова про які в Концепції реформування (розвитку) пенітенціарної системи України взагалі не ведеться. Як, власне, у зазначеній Стратегії і Концепції - про посилення громадського контролю за сферою виконання покарань, що $є$ надзвичайно важливим 3 огляду існуючої практики застосування фізичної сили, спеціальних засобів, гамівної сорочки та зброї до засуджених, позбавлених волі.

Висновки. Таким чином, розробляючи зазначену Концепцію, iї автори не в повній мірі кореспондували її положення з відповідним розділом Стратегії реформування судоустрою, судочинства та суміжних правових інститутів на 2015-2020 роки, що свідчить про безсистемний підхід до вирішення існуючих проблем і загроз національній безпеці, які мають місце у сфері виконання покарань України.

\section{Список використаної літератури}

1. Великий тлумачний словник сучасної української мови / укл. О. Єрошенко. Донецьк : ТОВ «Глорія Трейд», 2012. 864 с.

2. Керняневич-Танасійчук Ю. В. Кримінально-виконавча політика України : монографія. Івано-Франківськ : Прикарпат. нац. ун-т ім. Василя Стефаника, 2019. 336 с.

3. Богатирьов І. Г., Пузирьов М. С., Шкута О. О. Доктрина пенітенціарного права України : монографія. Київ : ВД «Дакор», 2017. 236 с.

4. Про схвалення Концепції реформування (розвитку) пенітенціарної системи України : Розпорядження Кабінету Міністрів України від 13.09.2017 р. № 654-Р. Урядовий кур'єр. 2017 р. № 178. 20 вересня. С. 8-9.

5. Булыко А. Н. Большой словарь иностранных слов. 35 тысяч слов. Изд. 3-е, испр., перераб. Москва : Мартин, 2010. 704 с.

6. Радов Г. О. Першочергові проблеми пенітенціарної політики України на сучасному етапі. Проблеми пенітенціарної теорї і практики. 1996. № 1. С.12-16.

7. Про національну безпеку України : Закон України від 21 червня 2018 року № 2469-VIII. Урядовий кур'єр. 2018. № 132.18 липня С. 2-5. 


\section{References}

Yeroshenko, O. (ukl.). (2012). Velykyi tlumachnyi slovnyk suchasnoi ukrainskoi movy. Donetsk : TOV «Hloriia Treid» [in Ukrainian].

Kernianevych-Tanasiichuk, Yu. V. (2019). Kryminalno-vykonavcha polityka Ukrainy. Ivano-Frankivsk: Prykarpat. nats. un-t im. Vasylia Stefanyka [in Ukrainian].

Bohatyrov, I. H., Puzyrov, M. S., Shkuta, O. O. (2017). Doktryna penitentsiarnoho prava Ukrainy. Kyiv: VD «Dakor» [in Ukrainian].

Bulyko, A. N. (2010). Bolshoi slovar ynostrannykh slov. 35 tysiach slov. Yzd. 3-e. Moskva : Martyn [in Russian].

Radov, H. O. (1996). Pershocherhovi problemy penitentsiarnoi polityky Ukrainy na suchasnomu etapi. Problemy penitentsiarnoi teorii i praktyky, 1, 12-16 [in Ukrainian].

O. Kolb, Doctor of Law, Professor, Professor of the Department of Criminal Law and Process of the Lviv Polytechnic National University

ORCID: 0000-0003-1792-4739

L. Duchiminska, the Head of Department of control and test work the headquarters of the Pension Fund of Ukraine in the Volyn region

\section{Modern policy in the sphere of execution of punishments of Ukraine: contents and features}

In scientific sources, politics means the general direction, nature of the activity of a state, a particular class, or a political party. On this basis, it is customary to distinguish foreign and domestic policy of the state. In turn, scholars, depending on the sphere of social relations, distinguish the legal, social, economic, cultural and other subspecies of the party's internal politics.

One of the types of legal policy is the state policy in the sphere of the execution of sentences of Ukraine, although at the doctrinal level, it is more about criminal enforcement and penitentiary policy.

Based on the theoretical postulates about the elements of implementation of state policy in the sphere of execution of penalties (normative-legal; organizationalinstitutional; guarantee; resource-providing; functional (instrumental); acts of Ukraine are the essence of the subspecies of domestic politics of Ukraine.

First of all, we are talking about Part 2 of Art. 1 of the Criminal Code of Ukraine, which sets out the following tasks of the penal law: 1) determination of the principles of execution of criminal penalties, legal status of convicted persons, guarantees of protection of their rights, legitimate interests and obligations; 2) determining the order of application of influence measures to them in order to correct and prevent asocial behavior; 3 ) definition of the system of bodies and institutions of execution of punishments, their functions and order of activity; 4) determining the order of supervision and control over the execution of criminal penalties, public participation in this process; 5) regulation of the procedure and conditions of execution and serving of criminal penalties; 6) regulation of the procedure for release from punishment, assistance to persons released from punishment, control and supervision of them. 
Therefore, only a superficial comparison of the statutory tasks of the state policy in the sphere of execution of penalties of Ukraine with the tasks of the penal policy, which are defined at the scientific level, gives grounds to claim that they are not identical (similar). That is the reason for the choice of the topic of this article, its relevance of theoretical and practical importance, and defined its main task - to develop scientifically sound measures aimed at improving the forms of its implementation at the legislative and practical levels, taking into account the current state strategies and concepts of reforming bodies and penal institutions.

Keywords: politics; sphere of execution of punishments; strategy; concept; body of execution of punishments; penal institution; reforming; probation. 